\title{
The impact of oil revenues on wellbeing in Chad
}

\author{
Gadom Djal Gadom ${ }^{1}$, Armand Mboutchouang Kountchou ${ }^{2 *}$ and Abdelkrim Araar $^{3}$ \\ ${ }^{1}$ University of N'Djamena and LAEREAG, N'Djamena, Chad; ${ }^{2}$ University of Dschang and REMA, \\ Yaoundé, Cameroon and ${ }^{3}$ Université Laval, Laval, Canada \\ ${ }^{*}$ Corresponding author. E-mail: mkountchou1@yahoo.fr
}

(Submitted 16 September 2017; revised 31 January 2018, 25 April 2018; accepted 14 May 2018; first published online 25 July 2018)

\begin{abstract}
This paper uses two recent household surveys, together with data from the College for Control and Monitoring of Oil Revenues, to analyse the impact of oil revenues on wellbeing in Chad. Following a multiple-correspondence analysis to estimate a synthetic householdbased multidimensional wellbeing (MDW) index, we used the difference-in-difference approach to assess the impact of oil revenues on average MDW at the department level. We found evidence that departments in Chad that received significant oil transfers have a higher MDW compared to those disadvantaged by the oil-revenue-redistribution policy. We conclude that, in order to promote economic inclusion, the government of Chad should better develop oil-revenue-redistribution policies according to local development needs and target the poorest departments.
\end{abstract}

Keywords: Chad; multidimensional wellbeing; oil revenues; poverty; redistribution policy

JEL Classification: C23, D63, I30, O18, Q32

\section{Introduction}

The extraction and exportation of oil produces specific socio-economic dynamics in developing countries, which, in turn, face important economic-policy challenges in trying to achieve economic development goals (IMF, 2012). Despite their vast oil wealth, countries in Central Africa appear more affected by the resource curse than are other developing countries, and this region still struggles to sustain strong and inclusive economic growth and to handle the unemployment which faces its fast-growing young population (Akitoby and Coorey, 2012). In this framework, some studies have focussed on oil-wealth management and its implications for poverty and inequality reduction in Central Africa in order to draw some helpful conclusions (Cash, 2012; Mabali and Mantobaye, 2017). In considering the case of Chad, this study aims to contribute to this literature. Chad has distinguished itself with respect to other oil producing countries in Africa by passing the specific Law 001/PR/1999 that constitutes the legal framework for oil revenue management and by creating the College for Control and Monitoring of Oil 
Revenues (CCMOR). ${ }^{1}$ These laws were implemented in order to better manage the oil revenue targeting Millennium Development Goals (MDGs).

There was investment in the oil sector in Chad by 2000, and oil production began effectively in October 2003 in the Doba basin. Oil exploitation contributed to a significant improvement in the country's macroeconomic performance. It represents 80 per cent of total exports and covers 75 per cent of the public budget since 2004. The annual economic growth rate, which averaged 4 per cent in the 1990s before oil exploitation, reached 7 per cent during the 2000s (INSEED, 2013). Indeed, the oil sector accounts for 84.5 per cent of exports, 71.3 per cent of ordinary budget revenues, and 14.2 per cent of gross domestic product (EITI, 2014). Despite this favorable pattern of macroeconomic indicators, the country has struggled to achieve MDGs (ECA, 2014). For instance, Chad was ranked 184th out of 187 countries on the human development index in 2013 (UNDP, 2013), and poverty remains high (at 47 per cent), having fallen only one percentage point per year on average between 2003 and 2011 (World Bank, 2013). The same source shows that important welfare disparities exist between the regions and inequality increased by 17 per cent, from 0.391 in 2003 to 0.456 in $2011 .^{2}$

Much of the debate around the governance of oil production, particularly in SubSaharan Africa, has focused on how to support policies that would prevent perverse effects of the natural resource. Scholars and policy makers are increasingly turning their thoughts to helping governments manage negative effects at local levels (Cust and Viale, 2016), predominantly in three main areas (Lipschutz and Henstridge, 2013). First, financial challenges related to revenue generation and management associated with the extraction sector, especially oil production. This is highlighted by the fact that Chad joined the Extractive Industries Transparency Initiative (EITI) in 2007, which advocates that payments made by companies should flow into government budgets and be monitored effectively. Second, negative effects of oil exploitation on the environment (contamination of ground water, accidental chemical spills, reduction in air quality, etc.) constitute a serious concern (Zhang et al., 2013). Chad has experienced accidental crudeoil spills in the past, one of the most tragic of which was the loss of about 200 barrels in October 2010. That spill led to an environmental catastrophe in the Kome district and seriously affected income-generating activities, especially agriculture. Lastly, social challenges related to citizens' living standards and wellbeing play an important role in strengthening policies reinforcing benefits of natural resources. Indeed, the small impact of natural-resource exploitation on citizens' wellbeing in Chad accentuated inequalities across administrative divisions in the country and led to ethnic conflicts and political instability. The recent 2005-2010 armed conflict is one such example (Ross, 2004; Hoinathy, 2013).

Despite the crucial role of financial and environmental concerns, our paper focuses on an assessment of the social impact of oil revenues redistribution in Chad. In the case of labor intensive sectors, the benefits can be distributed through labor incomes. In capital intensive sectors such as oil, however, social challenges could be tackled effectively through appropriate management of oil revenues (Sachs and Warner, 2001). This concern was effectively raised in Chad by the World Bank, which recommended

\footnotetext{
${ }^{1}$ The main role of the the College for Control and Monitoring of Oil Revenues is to allocate oil revenues to priority sectors and to control the effectiveness and quality of the investments made.

${ }^{2}$ Income inequality varied greatly across regions in 2011. Inequality was highest in Borkou/Ennedi/ Tibesti/Wadi-Fira and Tandjilé with Gini coefficients of 44.7 and 44.6 respectively. According to the World Bank (2013), this welfare discrepancy was accentuated after 2003 because of oil exploitation.
} 
the adoption of an oil-revenues-management-and-redistribution program to alleviate poverty, improve living conditions, and promote economic inclusion throughout the country (Ndang and Nan-Guer, 2011; Fondo et al., 2013; Thorbecke, 2013). Law 001/PR/99, enacted in 1999 after the discovery of the first oil wells, formalized such a program. The law explicitly states that 70 per cent of direct oil revenues are to be allocated to priority sectors (such as education, health, social affairs, infrastructure, agriculture, and rural development), 15 per cent to public investments, 5 per cent to the oil-producing department, and 10 per cent to future generations.

However, several stakeholders have denounced the government of Chad for failing to respect this program and for inappropriate and discretionary management of oil revenues (World Bank, 2013). This may accentuate variations in economic wellbeing across regions, counter to the Poverty Reduction Strategy Papers and the National Development Plan in Chad (Mabali and Mantobaye, 2017). This article therefore aims to provide a causal assessment of oil-revenue redistribution on household wellbeing at the local (department) level. We consider a hypothetical fair-redistribution policy that ensures that departments receive oil revenues proportionate to their population. ${ }^{3}$ This scenario serves as a treatment, and the difference-in-difference approach is used to assess the impact of oil revenue on average wellbeing at the department level before and after oil exploitation in Chad. We find evidence that economic inclusion in Chad would be better promoted if the government effectively directed oil-revenue redistribution toward local development needs and the poorest departments.

\section{Literature review}

Natural-resource exploitation is generally viewed as an opportunity for resource-rich countries to meet leadership and economic challenges, especially in developing countries. An extensive literature, inspired by the seminal papers of Sachs and Warner (Sachs and Warner, 1995, 1999, 2001), however, has pointed out the potentially adverse effects of natural-resource exploitation on economic development. Numerous studies have documented the macroeconomic effects of natural-resource exploitation, arguing that rent-seeking and Dutch disease are the main explanations for why an abundance of natural resources is not always a blessing, especially in a context of weak institutions (Gylfason, 2001; Acemoglu et al., 2004; Mehlum et al., 2006; Behbudi et al., 2010; Ebeke, 2015).

Although studies analyzing the macroeconomic effects of natural-resource exploitation are abundant, a growing number of economists have attempted to respond to the lack of studies that investigate the natural resource curse from a microeconomic or local perspective (Aragon and Rud, 2013; Lippert, 2014; Ticci and Escobal, 2015; Bauer et al., 2016; Loayza and Rigolini, 2016). An overview of literature on subnational effects of natural-resource exploitation highlights three main issues: the direct effects of particular projects (mining or hydrocarbon), the indirect effects of spending, and, finally, spillover effects from oil production in nearby departments (infrastructure, migration, and other opportunities' response to resource wealth) (Beine et al., 2015; Cust and Viale, 2016). Some empirical studies (Postali, 2009) have found no significant local effects of oil windfalls on living standards, as measured by welfare indicators (housing, education, health, road infrastructure, etc.). These studies established that municipalities which received

\footnotetext{
${ }^{3}$ Oil wells are not located in the regions which have received the important share of oil revenue compared to their population, such as Tibesti, Hadjer Lamis or Ennedi (see table A1 in the appendix).
} 
higher oil revenues scored worse on welfare indicators. The authors explain such results by pointing to centralized and local governance concerns characterized by misappropriation of funds or corruption within the decentralized fiscal system. Monge and Viale (2011) and Arellano-Yanguas (2011) similarly found that the spending of mining and hydrocarbon revenues across districts in Peru had a negligible impact.

Other studies challenge the finding that natural-resource revenues spent by subnational governments had either no effect or negative effects. Postali and Nishijima (2013), for instance, showed that royalties had a positive long-term social impact on household wellbeing in Brazil, especially in terms of increased literacy, access to electricity and water, and garbage collection. Cust and Rusli (2014), who noted that fiscal spillovers from local government spending (associated with revenue windfalls from extraction activity) played a role in Indonesia, found similar short-term economic performance.

Some studies have addressed the issue of how an egalitarian oil-revenueredistribution policy in Chad might play a positive role in reducing poverty disparities across the country (Ndang and Nan-Guer, 2011; World Bank, 2013; Allcott and Keniston, 2014; Gadom and Mboutchouang, 2016; Mabali and Mantobaye, 2017). To the best of our knowledge, however, ours is the first study that attempts to assess a causal link between oil revenues and household wellbeing.

Mabali and Mantobaye (2017), for example, attempted to assess the impact of oil revenues on wellbeing and poverty in Chad, though the study was limited in several ways. First, the authors did not consider how oil revenue was distributed across departments. Our 'treatment' group refers to the population that has received a significant part of oil revenue, but Mabali and Mantobaye (2017) define all departments in the period following oil exploitation as treated. This simplification severely biases the results because not all departments receive oil revenues and, among those that do, treatment differs substantially. The second improvement in our application is that, instead of using the Alkire and Santos (2010) multidimensional poverty index (according to which some predefined dimensions of wellbeing must be used), we base our multidimensional wellbeing (MDW) on the specificities of the actual context in Chad.

\section{Data and methodology}

The data we used were drawn from the last two Chad Household Consumption and Informal Sector Surveys, ECOSITs 2 and 3, conducted by the National Institute of Statistics, Economic, and Demographic Studies (INSEED) in 2003 and 2011, respectively. These databases were valuable to our study for three main reasons. First, they constituted unique data sets for analyzing non-monetary wellbeing. Second, their stratified sampling design encompassed administrative departments throughout the country. Third, they provided a suitable framework for conducting an impact-evaluation analysis (ECOSITs 2 and 3 offered pre- and post-intervention information regarding the exploitation of oil resources, which began in 2003). These household surveys included administrative data on oil revenues allocated across departments by the CCMOR since 2005. A specific harmonization at the post-intervention level is required to match both data sources at the departmental level (see appendix A).

Based on the assumption that the Oil-Revenue Redistribution Policy (ORRP) may improve living standards across departments in the form of local social investments in health, education, water services, and infrastructure, for example, all of which are mainly financed by oil revenues in Chad, our objective was to assess the local impact of ORRP 
on MDW. To do this, we conducted an impact-evaluation analysis based on a hypothetical oil-revenue-redistribution mechanism. Indeed, to better alleviate the resource curse, natural-resource governance requires redistribution mechanisms tailored to local development needs. Several works discuss the social and economic efficiencies of various mechanisms for the redistribution of natural-resource revenues around the world (Salai-Martin and Subramanian, 2003; Sandbu, 2006; Segal, 2011; Maguire and Winters, 2017). Thus, assuming that development needs are highly correlated to population, it is possible to calculate a ratio for each department that indicates whether the redistribution policy has or has not been favorable. The ratio is:

$$
r_{d}=\frac{\text { Oil Revenues Budget }_{\text {Department }} / \text { Oil Revenues Budget }_{\text {National }}}{\text { Population }_{\text {Department }} / \text { Population }_{\text {National }}}=\frac{\text { Oil }_{d}}{\text { Dem }_{d}} \text {, }
$$

where $\mathrm{Oil}_{d}$ represents the percentage of oil revenues received by the department $d$, and $\mathrm{Dem}_{d}$ indicates the demographic weight of the department with respect to the national population. ${ }^{4}$ A ratio $r_{d}<1$ shows that the share of oil revenues received by a given department is lower than the department's size relative to the national population. In such cases, redistribution seems disadvantageous because the percentage of oil revenues received does not match the population of that department. Conversely, a ratio $r_{d}>1$ indicates that the redistribution policy is favorable for the department, and if $r_{d}=1$, we assume, based on the population of the department, that treatment is equitable. In the event of $r_{d}=1$, the per capita oil revenue for the department is exactly equal to the national distribution ratio, as shown in equation (2).

$$
r_{d}=1 \text { if } \frac{\text { Oil Revenues Budget }_{\text {Department }}}{\text { Population }_{\text {Department }}}=\frac{\text { Oil Revenues Budget }_{\text {National }}}{\text { Population }_{\text {National }}} .
$$

Appendix B shows the values of $\mathrm{Dem}_{d}, \mathrm{Oil}_{d}$ and $r_{d}$ for each department.

We assumed that the treated departments were those that received a per capita oil revenue that was equal to or higher than the national per capita level. Indeed, the ratio $r_{d}$ allowed us to build two groups of departments according to the oil transfers they received during the post-intervention period (after 2003). The first group included treated departments for which the $r_{d}$ ratio is greater than or equal to 1 . The second group of untreated departments was disadvantaged by the redistribution policy, and their $r_{d}$ ratio was consequently less than 1 . To sum up, within a setting of $N$ departments in Chad, $N_{1}<N$ departments scoring a ratio $r_{d} \geq 1$ were the treatment group, while the remaining $N_{0}=N-N_{1}$ departments represented the control group.

Following Zambrano et al. (2014), we also assumed that two potential outcomes existed for each department $d \in[1, N)$. First, $Y_{d}(0)$ denotes the outcome that would have resulted had the department $d$ not received oil shares that were at least proportional to those allocated nationally. On the other hand, $Y_{d}(1)$ denotes the outcome that would have resulted had department $d$ received oil shares that were not disadvantageous with

\footnotetext{
${ }^{4}$ The percentage of oil revenues is computed through CCMOR data based on the average of direct oil revenues redistributed throughout the country between 2008 and 2011. Information before 2008 is not available, while data after 2011 go beyond the scope of this study. Demographic weights are provided by the second General Population and Housing Census conducted by INSEED in 2009, however. These demographic weights are easily calculated for 2011 under the assumption that the population did not change significantly between the two dates.
} 
respect to its share of the population. In a difference-in-difference (DID) framework, the difference $Y_{d}(1)-Y_{d}(0)$ represents the causal effect at the department level. These two potential outcomes are mutually exclusive; only one of them can be realized. A DID approach, then, is the appropriate method for estimating the average effect of the treatment. ${ }^{5}$ We implemented the DID estimate within a linear regression framework. Our basic model follows Imbens and Wooldridge (2009):

$$
Y_{d t}=\alpha+\gamma . T+\lambda . D_{d}+\delta .\left(T . D_{d}\right)+\beta . X_{d t}+\varepsilon_{d t},
$$

where $Y_{d t}$ is the outcome (average MDW score) in department $d$ at time $t$. Appendix C presents the construction of the synthetic index of MDW based upon a large set of welfare and access-to-facilities indicators. $T$ is a dummy variable equal to 0 in the preintervention period (2003) and 1 in the post-intervention period (2011); $D_{d}$ is a dummy variable equal to 1 for the treated department and 0 otherwise; $X_{d t}$ is a set of timeinvariant and department-level characteristics for each time period ${ }^{6}$; and $\varepsilon_{d t}$ represents the error term assumed to be independent and identically distributed.

Coefficient $\delta$ is the main parameter of interest because it represents the DID estimate of the average effect of oil revenues. Coefficient $\alpha$, meanwhile, indicates the full set of dummies per department. For the DID estimators to be interpreted correctly, we make the following assumptions: $\operatorname{cov}\left(\varepsilon_{d t}, T\right)=0 ; \operatorname{cov}\left(\varepsilon_{d t}, D_{d}\right)=0$; and $\operatorname{cov}\left(\varepsilon_{d t}, T . D_{d}\right)=$ 0 . This last covariance shows the most critical assumption - the parallel trend assumption, meaning that unobserved characteristics that affect treatment assignment for each department (oil-revenue redistribution) do not vary over time with treatment status.

Normally, the Ashenfelter dip test is used to assess violation of the parallel-trend assumption. Unfortunately, this test cannot be performed as it requires data from more than two periods that we do not have. Note that, in the classic DID model, the implicit assumption is that of constant return of the endowments. Thus, the characteristics and the assets of the two groups of the population (treated and untreated) can differ. Such a difference enables sample-bias correction. By using the traditional DID model, we assumed that the parallel-path assumption held, which requires the time effect to be the same for the treated and untreated groups. For instance, if we applied a second program to the treated group without considering such a program, the estimated impact would capture joint effects. Thus, in this case, the estimated effect cannot be attributed solely to the first program, and the parallel assumption is violated. Unfortunately, as was the case for several empirical studies, the test of the parallel assumption also requires data from more than two periods, which we did not have. Note that the DID model makes it possible to overcome the randomization constraint of the treatment by assuming the full independence of the other covariates and a constant return of the treatment. Indeed,

\footnotetext{
${ }^{5}$ Some departments are exposed to the treatment (significant oil revenues $r_{d} \geq 1$ ) while others are not. In our two-period setting (before and after 2003), DID estimates bypass biases in second-period comparisons that could be the result of permanent differences between treated and untreated departments, as well as biases arising from time trends unrelated to oil-revenue transfers. Indeed, according to the paralleltrend assumption, the DID approach assumes that, in the absence of oil transfers (pre-intervention period), temporal trends in outcomes across treated and untreated departments would be the same.

${ }^{6}$ Several controls - population density and geographical controls (altitude, area, regional or provincial capital dummies, for example) - are used in empirical studies (see Zambrano et al., 2014, and Loayza and Rigolini, 2016). Lack of data led us to retain two variables: population density for each department in 2003 and 2011 and each department's distance from the capital city of N'Djamena. Their squared values are believed to capture a curvilinear relationship with the MDW score.
} 
Table 1. Definition of variables and descriptive statistics

\begin{tabular}{|c|c|c|c|c|c|}
\hline Variables & $\begin{array}{c}\text { Year } \\
\text { (Std. dev.) }\end{array}$ & $\begin{array}{c}\text { Overall } \\
\text { (Std. dev.) }\end{array}$ & $\begin{array}{l}\text { Treated } \\
\text { (Std. dev.) }\end{array}$ & $\begin{array}{l}\text { Untreated } \\
\text { (p-value) }\end{array}$ & $t$-test \\
\hline \multirow{3}{*}{$\begin{array}{l}\text { MDW (average } \\
\text { scores of } \\
\text { multidimen- } \\
\text { sional } \\
\text { wellbeing } \\
\text { index) }\end{array}$} & All & $0.6799(0.5005)$ & $0.7997(0.6449)$ & $0.6417(0.4422)$ & $0.158^{*}(0.066)$ \\
\hline & 2003 & $0.6624(0.5668)$ & $0.6548(0.5227)$ & $0.6648(0.5856)$ & -0.059 \\
\hline & 2011 & $0.6974(0.4279)$ & $0.9446(0.7371)$ & $0.6185(0.2264)$ & $2.698^{* * *}(0.004)$ \\
\hline $\begin{array}{l}\text { Ratio } \\
\text { (computed } \\
r_{d} \text { ratio) }\end{array}$ & All & $0.8390(1.5270)$ & $2.7135(2.2103)$ & $0.2394(0.2520)$ & $2,474^{* * *}(0.000)$ \\
\hline \multirow{3}{*}{$\begin{array}{l}\text { Density of } \\
\text { population } \\
\text { (inhabitants } \\
\text { of } \\
\text { department } \\
\text { d } / \mathrm{km}^{2} \text { ) }\end{array}$} & All & $49.309(86.942)$ & $69.038(94.759)$ & $43.013(83.855)$ & $26.024^{*}(0.077)$ \\
\hline & 2003 & $28.627(52.577)$ & $35.880(50.414)$ & $26.313(53.568)$ & $0.610(0.728)$ \\
\hline & 2011 & $69.992(107.74)$ & $102.19(117.05)$ & $59.714(103.81)$ & $1.338 *(0.092)$ \\
\hline \multirow{3}{*}{$\begin{array}{l}\text { Squared } \\
\text { density of } \\
\text { population }\end{array}$} & All & 9929.4 (40487.8) & $13446(33,256)$ & $8,807.1(42,636)$ & $4,639.2(0.293)$ \\
\hline & 2003 & $3,539.3(16,134.9)$ & $3,659.5(10,181.6)$ & $3,500.9(17,710.7)$ & $0.032(0.513)$ \\
\hline & 2011 & $16,319.6(54,424.7)$ & $23,233.1(44,521.2)$ & $14,113.2(57,481.4)$ & $0.561(0.288)$ \\
\hline $\begin{array}{l}\text { Distance from } \\
\text { department } \\
\text { d to } \\
\text { N’Djamena } \\
\left(\mathrm{km}^{2}\right)\end{array}$ & All & 441.17 (251.033) & $469.63(312.85)$ & 432.09 (229.08) & $37.54(0.239)$ \\
\hline $\begin{array}{l}\text { Squared } \\
\text { distance to } \\
\text { N'Djamena }\end{array}$ & All & $257,143(286,739)$ & $315,171(357,789)$ & $238,624(259,597)$ & $76,547.5(0.102)$ \\
\hline N (Obs.) & & 124 & 30 & 94 & \\
\hline
\end{tabular}

Note: ${ }^{* * *}$ and ${ }^{*}$ indicate the significance levels at 1 and $10 \%$ respectively.

Source: Authors' estimation.

in the case in which treatment is affected by initial endowments, the estimated impact can be attributed to the treated group. Even in this case, however, the study enables us to show the nature of the impact of the treatment. Chabé-Ferret (2015) indicated that, in the case of permanent fixed effects with transitory shocks, combining DID with conditioning on pre-treatment outcomes is either irrelevant or inconsistent.

Table 1 provides definitions of explanatory variables and descriptive statistics. The average MDW score in the sample is 0.6799 (range: 0.2682 to 3.2439), and mean population density in departments is about 49 inhabitants per $\mathrm{km}^{2}$, while the distance from departments to N'Djamena is, on average, $441.17 \mathrm{~km}^{2}$. It is also interesting to observe descriptive statistics regarding the treated and untreated subsamples. We find mean values to be higher for the treated group. For instance, treated departments scored an average MDW of 0.7997 compared to 0.6417 in the untreated group. The statistics are similar for other variables, especially population density and distance to N'Djamena. The mean values of the computed-ratio variable confirm the treatment assignment 
because that value is greater than one (2.7135) in the treated group and less than one (0.2394) in the control group. Further, a means comparison test shows a significant difference between treated and untreated department regarding their MDW and density of population.

Given the panel-data setting, equation (3) was estimated using DID-panel models. Fixed Effects (FE) and Random Effects (RE) models were estimated successively. For the choice between RE and FE models, we used the auxiliary test proposed by Mundlak (1978), which is valid even under heteroscedasticity (see also Wooldridge, 2010). Note that the RE Model is based on the assumption of unrelated effects or on no correlation between the error term and the observables (X covariates).

\section{Application and results}

\subsection{Some salient facts regarding wellbeing and oil-revenue redistribution in Chad}

We start by showing descriptive evidence of the change in average wellbeing scores for each department between 2003 and 2011, as well as a potential link between MDW and oil-revenue redistribution in Chad. At a national level, population wellbeing has increased from 0.596 to 0.616 over the period in question - perhaps as a result of oil exploitation. This argument is confirmed at the local level by observation of the evolution of MDW scores according to oil-revenue distribution across departments. These spatial descriptive statistics are shown in figure 1.

One can note that in general, when the main mineral resource is owned and exploited by the state, we do not observe a significant linkage between the revenues of the population living in the localities of exploitation and the revenues of exploitation. Panel A of figure 1 shows that the largest improvements were recorded in Ennedi East, Ennedi West, Lac Wey, Barh Azoum, N’Djamena, and Kabbia, which are far from the localities of oil exploitation. Inversely, the lowest performances were in Haraze Mangueigne, Lac Léré, Tibesti, and Dar Tama. These departments are characterized by a deprivation of basic infrastructure such as schools, hospitals, roads, and electricity. The observed disparities may be attributed to unequal oil-revenue distribution which affects infrastructure investments that could reduce poverty in poor departments. Indeed, as we can observe in figure 1, panel B, Ennedi East and Ennedi West received the highest per capita oil revenues. For the rest of departments, we also observed a positive correlation between oil revenue and improvement in MDW. An exception occurs in Tibesti, where the contrast may be explained by recurrent political instability.

\subsection{Discontinuous effects of oil revenues on multidimensional wellbeing}

The results presented in table 2 show our DID estimate of the discontinuous effects of ORRP applied across departments. We estimated that, on average, departments that received significant oil transfers $\left(r_{d} \geq 1\right)$ increased their MDW more than those disadvantaged by the ORRP. Although coefficients are not equal, these positive local effects remain robust and significant at the 5 per cent level of significance for both FE Effects and RE models. A modified Wald test, however, showed that error terms exhibited groupwise heteroscedasticity ( $p$-value $=0.000)$. In addition, the auxiliary test for the unrelated-effect assumption $^{7}$ led us to reject the RE assumption ( $p$-value $\left.=0.176\right)$.

\footnotetext{
${ }^{7}$ This assumption considers that department-specific effects are uncorrelated with the explanatory variables of the same department over time.
} 
Panel A

Evoluation of Multidimensional Well-being

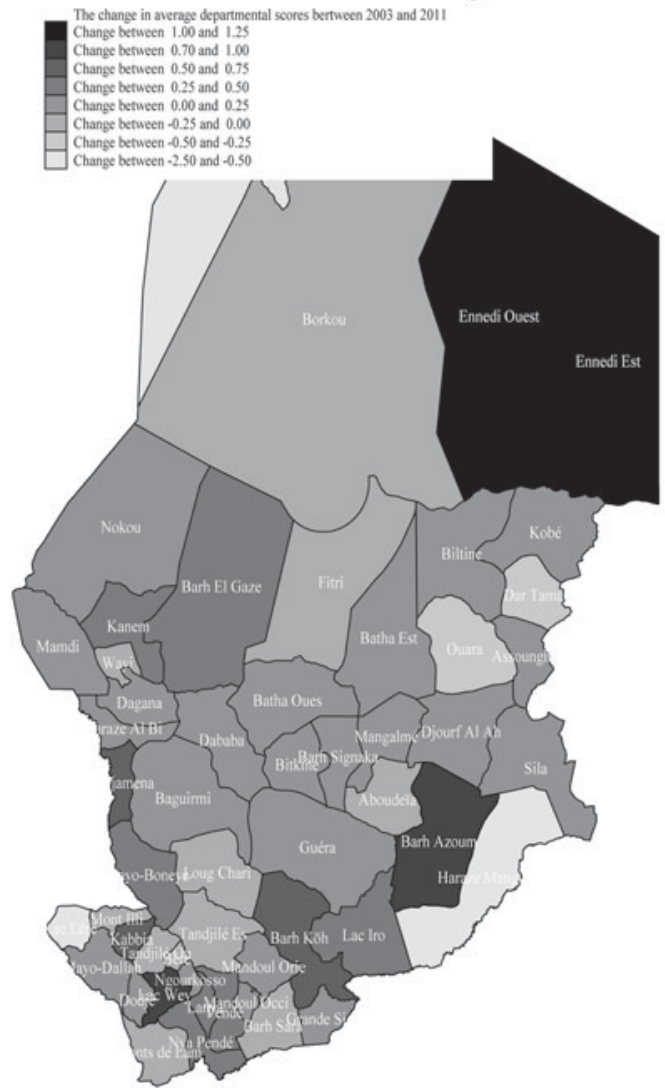

Panel B

The distribution of oil revenue across departments

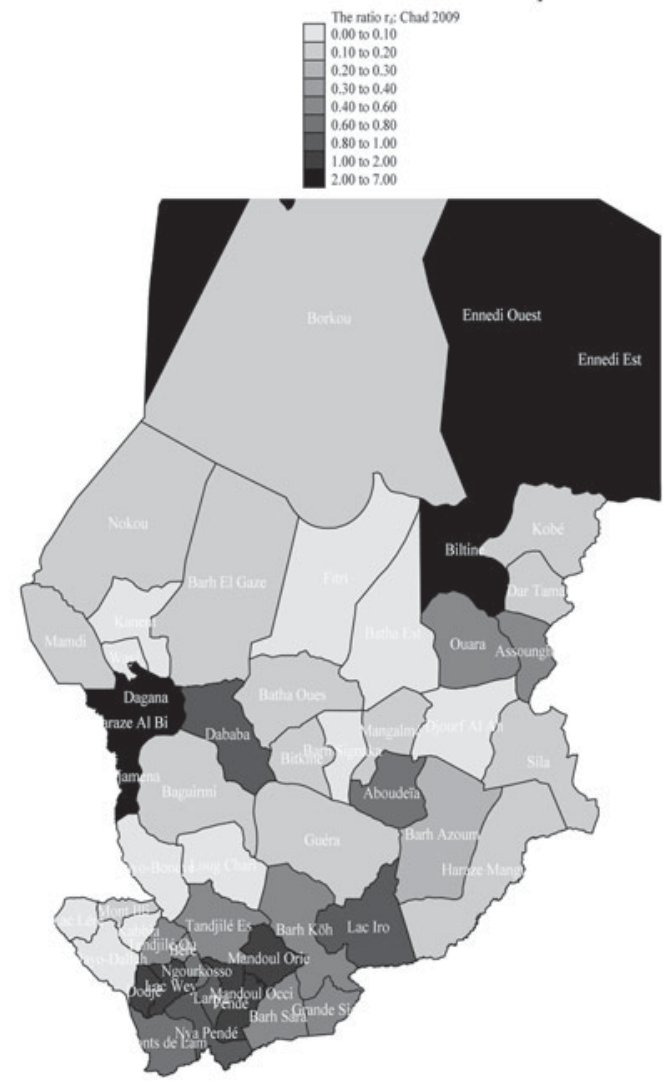


Table 2. DID Estimates of the impact of significant oil revenues on MDW - binary treatment

\begin{tabular}{|c|c|c|c|c|c|c|}
\hline \multirow[b]{2}{*}{ Variables } & \multicolumn{2}{|c|}{ Treatment $r_{d} \geq 0.9$} & \multicolumn{2}{|c|}{ Treatment $r_{d} \geq 1$} & \multicolumn{2}{|c|}{ Treatment $r_{d} \geq 1.1$} \\
\hline & F.E. & R.E. & F.E. & R.E. & F.E. & R.E. \\
\hline \multicolumn{7}{|c|}{ Basic DID dummy variables } \\
\hline Time & $\begin{array}{r}-0.032286 \\
(0.099154)\end{array}$ & $\begin{array}{r}-0.088831 \\
(0.099840)\end{array}$ & $\begin{array}{r}-0.036982 \\
(0.100738)\end{array}$ & $\begin{array}{r}-0.092947 \\
(0.098978)\end{array}$ & $\begin{array}{l}(0.097432) \\
(0.097432)\end{array}$ & $\begin{array}{c}-0.089126 \\
(0.095309)\end{array}$ \\
\hline Treatment & & $\begin{array}{r}-0.112995 \\
(0.117875)\end{array}$ & & $\begin{array}{r}-0.099949 \\
(0.122242)\end{array}$ & & $\begin{array}{c}-0.088026 \\
(0.120165)\end{array}$ \\
\hline $\begin{array}{l}\text { Time } \times \\
\text { Treatment }\end{array}$ & $\begin{array}{c}0.35646^{* *} \\
(0.143260)\end{array}$ & $\begin{array}{c}0.258156^{*} \\
(0.140945)\end{array}$ & $\begin{array}{c}0.34922^{* *} \\
(0.136368)\end{array}$ & $\begin{array}{c}0.28986^{* *} \\
(0.137958)\end{array}$ & $\begin{array}{c}0.3895^{* * *} \\
(0.141217)\end{array}$ & $\begin{array}{c}0.32514^{* *} \\
(0.144035)\end{array}$ \\
\hline \multicolumn{7}{|c|}{ Department characteristics } \\
\hline $\begin{array}{l}\text { Density of } \\
\text { population }\end{array}$ & $\begin{array}{r}-0.001504 \\
(0.001575)\end{array}$ & $\begin{array}{c}0.001452 \\
(0.001345)\end{array}$ & $\begin{array}{r}-0.001114 \\
(0.001487)\end{array}$ & $\begin{array}{c}0.001454 \\
(0.001294)\end{array}$ & $\begin{array}{c}0.001150 \\
(0.001471)\end{array}$ & $\begin{array}{l}0.001386 \\
0.001386\end{array}$ \\
\hline $\begin{array}{l}\text { Squared density } \\
\text { of population }\end{array}$ & $\begin{array}{c}0.000002 \\
(0.000002)\end{array}$ & $\begin{array}{c}-0.0000002 \\
(0.000002)\end{array}$ & $\begin{array}{c}0.000002 \\
(0.000002)\end{array}$ & $\begin{array}{c}-0.0000001 \\
(0.000002)\end{array}$ & $\begin{array}{c}0.000002 \\
(0.000002)\end{array}$ & $\begin{array}{c}-0.0000001 \\
(0.000002)\end{array}$ \\
\hline $\begin{array}{l}\text { Distance to } \\
\text { N'Djamena }\end{array}$ & & $\begin{array}{r}-0.001799 \\
(0.001305)\end{array}$ & & $\begin{array}{r}-0.001760 \\
(0.001281)\end{array}$ & & $\begin{array}{c}-0.001703 \\
(0.001269)\end{array}$ \\
\hline $\begin{array}{l}\text { Squared } \\
\text { distance to } \\
\text { N'Djamena }\end{array}$ & & $\begin{array}{c}0.000001^{*} \\
(0.000001)\end{array}$ & & $\begin{array}{c}0.000001^{*} \\
(0.000001)\end{array}$ & & $\begin{array}{c}0.000001^{*} \\
(0.000001)\end{array}$ \\
\hline Constant & $\begin{array}{l}0.695117^{* * *} \\
(0.051117)\end{array}$ & $\begin{array}{l}0.957571^{* * *} \\
(0.310014)\end{array}$ & $\begin{array}{l}0.685042^{* * * *} \\
(0.047862)\end{array}$ & $\begin{array}{l}0.944760^{* * *} \\
(0.304104)\end{array}$ & $\begin{array}{l}0.686308^{* * *} \\
(0.047492)\end{array}$ & $\begin{array}{l}0.928670^{* * *} \\
(0.302297)\end{array}$ \\
\hline $\begin{array}{l}\text { Observations } \\
(\mathrm{N})\end{array}$ & 124 & 124 & 124 & 124 & 124 & 124 \\
\hline $\begin{array}{l}\text { Within } \\
\qquad \begin{array}{l}R \text {-squared } \\
\left(R^{2}\right)\end{array}\end{array}$ & 0.075 & 0.042 & 0.074 & 0.048 & 0.080 & 0.055 \\
\hline $\begin{array}{l}\text { Between } \\
\quad R \text {-squared } \\
\left(R^{2}\right)\end{array}$ & 0.001 & 0.259 & 0.021 & 0.261 & 0.029 & 0.262 \\
\hline $\begin{array}{l}\text { Overall } \\
\qquad \begin{array}{l}R \text {-squared } \\
\left(R^{2}\right)\end{array}\end{array}$ & 0.019 & 0.180 & 0.039 & 0.184 & 0.047 & 0.188 \\
\hline $\begin{array}{l}\text { Heteroscedasticity } \\
\text { (p-value) }\end{array}$ & 0.000 & & 0.000 & & 0.000 & \\
\hline $\begin{array}{c}\text { Auxiliary test } \\
\text { ( } p \text {-value) }\end{array}$ & 0.115 & & 0.176 & & 0.184 & \\
\hline
\end{tabular}

Notes: Discrete change of dummy variable from 0 to $1 .{ }^{*} p<0.10,{ }^{* *} p<0.05$, ${ }^{* * *} p<0.01$. Robust standard errors in brackets.

Source: ECOSIT 2 and 3.

Our results are in line with several other empirical studies. Arreaza and Reuter (2012), for instance, who also used a DID approach in their case study of Peru, found that mining transfers had a positive impact on expenditures, but noted no significant differences in terms of the provision of public goods across recipient and non-recipient districts. 
Similar results were obtained by Zambrano et al. (2014), who found a trend which suggested that mining-revenue transfers had marginal positive effects on reduction of poverty and inequality. Furthermore, Caselli and Michaels (2013) found extremely small effects of revenues from oil on reported real spending in public services (housing, transportation, education, health, and social transfers) in Brazil.

We added covariates to the treatment variable in order to control for heterogeneity effects. In particular, these included population density per $\mathrm{km}^{2}$ and its squared value as well as the distance of the department to N'Djamena and its squared value. Obviously, a large number of other covariates may explain MDW levels. We preferred to avoid redundancy, however, because these covariates were already used as basic indicators of MDW. Results showed that there were some positive externalities for departments closest to the capital city N'Djamena because they scored higher MDW. ${ }^{8}$ The concentration of oil-revenue investment in the capital city and its neighboring departments may explain such a result. Nevertheless, the relationship between the distance to N'Djamena and the levels of MDW is nonlinear because the squared distance is positive and significant.

However, the R-squared values provide information about the goodness-of-fit of different estimation models. Obviously, the RE models increase the quantity of variance of the model to be explained. The R-squared is in general lower for FE models compared to RE models. Considering a threshold of the treatment of 1.0, for instance, the covariates explain 18.4 per cent of the overall estimated variance when the random effects are considered, but 3.9 per cent only for the fixed effects. The between R-squared value is higher (0.261). In addition, the R-squared increases with the threshold of the treatment $(0.9,1.0$ and then 1.1). Thus, the higher the threshold is, the better is the significance of the impact.

\subsection{Sensitivity analyses and robustness checks}

Several analyses were conducted to capture sensitivity and check the robustness of our results. First, we considered the ratio threshold $r_{d} \geq 1$, excluding departments whose ratios were just below or above 1 from the treatment group. The MDW of excluded departments may also be affected by oil revenue, however. Consequently, we observed that our results were sensitive to two other ratio thresholds, $r_{d} \geq 0.9$ and $r_{d} \geq 1.1$. Results reported in table 2 show that the arbitrariness of the threshold was not a serious challenge. Indeed, results obtained for all ratio thresholds were very similar. Significant oil revenues received by treated departments led them to increase their average MDW significantly in comparison to untreated departments. This positive local effect is robust and significant at the 1 per cent level for the ratio threshold $r_{d} \geq 1.1$.

Second, in addition to a binary-treatment approach, it is also important to capture the intensity effects of oil revenues by considering a continuous form of the treatment

\footnotetext{
${ }^{8}$ Usually, studies that analyze the local impact of natural-resource exploitation account for neighboring spillover effects. These effects, however, could not be considered in our study because of the lack of data. ECOSITs 2 and 3 did not take into account the environmental issues in the survey. In addition, unlike other forms of mining activities, oil exploitation is not likely to be the subject of spillover effects (Loayza and Rigolini, 2016). Because mining activities are labor-intensive, job opportunities in departments in which mining occurs would exist for workers living in nearby departments. However, oil exploitation requires more skilled jobs and is mainly intensive in capital and in technology. There are fewer job opportunities in the oil sector, and even workers who live in an oil-producing department might not have the opportunity to take advantage of oil-industry jobs. Consequently, we have not taken neighboring spillover effects into account.
} 
Table 3. DID estimates of the local impact of significant oil revenues on MDW - continuous treatment

\begin{tabular}{|c|c|c|c|c|}
\hline \multirow[b]{2}{*}{ Variables } & \multicolumn{2}{|c|}{ Without department covariates } & \multicolumn{2}{|c|}{ With department covariates } \\
\hline & F.E. & R.E. & F.E. & R.E. \\
\hline \multicolumn{5}{|c|}{ Basic DID dummy variables } \\
\hline Time & $\begin{array}{r}0.138026^{*} \\
(0.080996)\end{array}$ & $\begin{array}{c}0.159879 \\
(0.099764)\end{array}$ & $\begin{array}{c}0.137901 \\
(0.112777)\end{array}$ & $\begin{array}{c}0.054890 \\
(0.095015)\end{array}$ \\
\hline Time $\times$ Ratio & $\begin{array}{r}0.081546^{*} \\
(0.045735)\end{array}$ & $\begin{array}{l}0.098846^{* *} \\
(0.049520)\end{array}$ & $\begin{array}{c}0.078836 \\
(0.047643)\end{array}$ & $\begin{array}{r}0.062755^{*} \\
(0.035961)\end{array}$ \\
\hline \multicolumn{5}{|c|}{ Department characteristics } \\
\hline Density of population & & & $\begin{array}{r}-0.000595 \\
(0.001574)\end{array}$ & $\begin{array}{c}0.001658 \\
(0.001325)\end{array}$ \\
\hline $\begin{array}{l}\text { Squared density of } \\
\text { population }\end{array}$ & & & $\begin{array}{c}0.000001 \\
(0.000002)\end{array}$ & $\begin{array}{r}-0.0000007 \\
(0.000002)\end{array}$ \\
\hline $\begin{array}{l}\text { Distance to } \\
\text { N'Djamena }\end{array}$ & & & & $\begin{array}{r}-0.001683 \\
(0.001266)\end{array}$ \\
\hline $\begin{array}{l}\text { Squared distance to } \\
\text { N'Djamena }\end{array}$ & & & & $\begin{array}{c}0.000001^{*} \\
(0.000001)\end{array}$ \\
\hline Constant & $\begin{array}{l}0.662438^{* * *} \\
(0.036843)\end{array}$ & $\begin{array}{l}0.662438^{* * *} \\
(0.072588)\end{array}$ & $\begin{array}{l}0.673577^{* * *} \\
(0.047881)\end{array}$ & $\begin{array}{l}0.902900 * * * \\
(0.303806)\end{array}$ \\
\hline Observations (N) & 124 & 124 & 124 & 124 \\
\hline Within $R$-squared $\left(R^{2}\right)$ & 0.044 & 0.044 & 0.049 & 0.029 \\
\hline $\begin{array}{l}\text { Between } R \text {-squared } \\
\quad\left(R^{2}\right)\end{array}$ & 0.055 & 0.055 & 0.060 & 0.269 \\
\hline $\begin{array}{l}\text { Overall } R \text {-squared } \\
\qquad\left(R^{2}\right)\end{array}$ & 0.049 & 0.049 & 0.053 & 0.184 \\
\hline $\begin{array}{l}\text { Heteroscedasticity } \\
\quad(p \text {-value })\end{array}$ & 0.000 & & 0.000 & \\
\hline $\begin{array}{l}\text { Auxiliary test } \\
\text { ( } p \text {-value) }\end{array}$ & 0.563 & & 0.431 & \\
\hline
\end{tabular}

Notes: Discrete change of dummy variable from 0 to $1 .{ }^{*} p<0.10,{ }^{* *} p<0.05,{ }^{* *} p<0.01$. Robust standard errors in brackets.

Source: ECOSIT 2 and 3.

indicator, which is, in our case, the computed ratio. For this purpose, we proposed using the DID continuous treatment model $^{9}$ :

$$
Y_{d t}=\alpha+\gamma \cdot T+\delta .\left(T \cdot r_{d}\right)+\beta . X_{d t}+\varepsilon_{d t} .
$$

The results of the FE and RE models are summarized in table 3. Although local effects were less robust than in binary treatment, results from continuous treatment were generally consistent and confirmed that department oil-revenue transfers had a positive impact on MDW. With regard to the goodness-of-fit of the models, we observe the same

\footnotetext{
${ }^{9}$ This model is mainly inspired by Acemoglu et al. (2004) and Goldin and Olivetti (2013), who assessed the role of World War II on the female labor supply in the USA.
} 


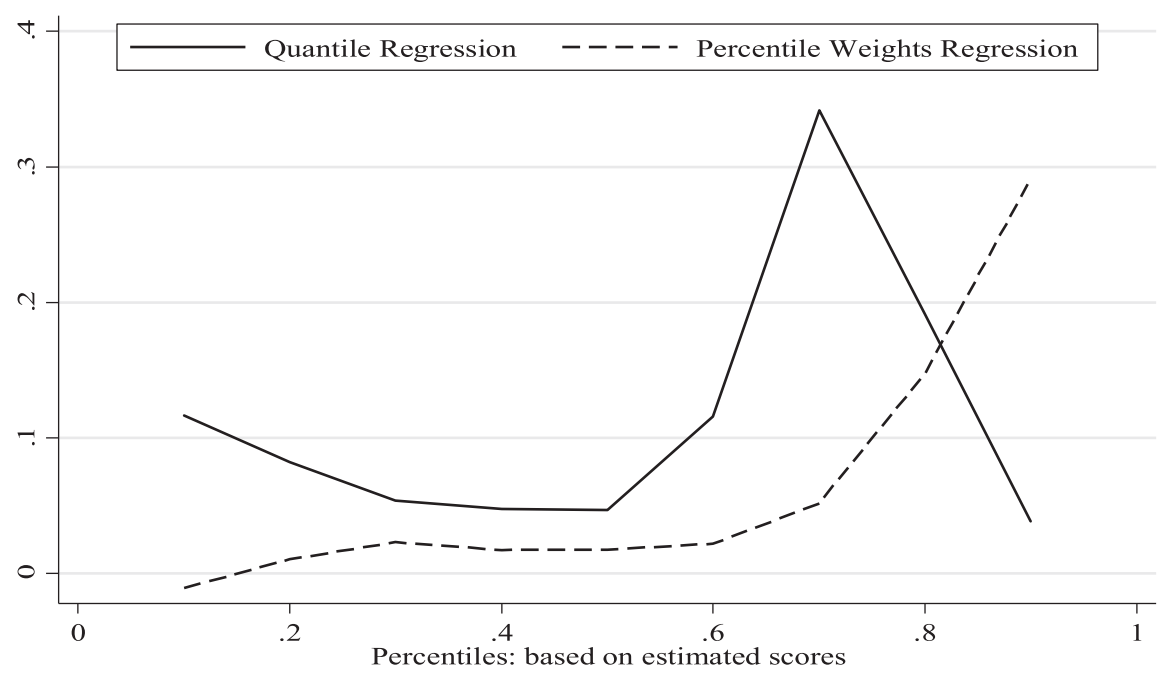

Figure 2. Local effects of significant oil revenues with QR and PWR models. Source: ECOSIT 2 and 3.

tendency compared to the results of table 2, and where the explained variability with the RE models continues to be higher than that of the FE models. Similarly, with the continuous form of the treatment, the RE model explains about 18.4 per cent of the total variability.

Finally, ${ }^{10}$ another important question is whether the effects of the treatment differ according to initial level of MDW. The Quantile Regression (QR) model, which assesses the effects of treatment at a given percentile of MDW scores, is typically used to show such heterogeneity in the impact of treatment. In addition to the QR model, Araar (2016) suggested Percentile Weights Regression (PWR) as a complementary model to assess heterogeneity. In figure 2, we show the impact of treatment with both models according to MDW percentiles. For the two econometric models, the impact of treatment increased in general with levels of wellbeing. In other words, in the departments with a high average MDW, significant oil revenues had greater impact effects on MDW. This can be explained by the cumulative effects of oil transfers which were not considered in our models because of lack of data. It can be noted that the results of the two models are quite different at higher percentiles. As was reported by Araar (2016), results of the QR model can be highly sensitive to the impact of treatment at percentiles that are far from the percentile of interest, thus explaining the difference in results between the two models.

\footnotetext{
${ }^{10}$ In addition, we also performed tests of outliers. Results showed an acceptable level of robustness. Indeed, based on Cook's distance, we found no outlier problem from extreme ratio values of 16.3, 62, 7.6, and 8.9 for the Tibesti-Est, Biltine, Dagana, and Ennedi departments, respectively. Only N'Djamena significantly influenced estimates. If the two N'Djamena observations are removed from the analysis, however, the results remain substantially the same.
} 


\section{Conclusion}

The three sources through which extraction of natural resources such as crude oil has social effects at the subnational level are: extraction activity, the revenues generated by extraction that are allocated and spent at the subnational level, and local spillovers. This paper investigated narrowly the second source and aimed to evaluate, with a local perspective, the impact of oil-revenue-redistribution policy on wellbeing at the department level in Chad. To do this, we considered an impact-evaluation-analysis framework based on a hypothetical scenario in which oil-revenue-redistribution mechanisms across departments effectively matched local development needs on the basis of each department's demographic weight.

As expected, spatial descriptive statistics shed light on a potential link between oilrevenue redistribution and changes in average department wellbeing scores between 2003 (before oil exploitation) and 2011 (after oil exploitation). These results conformed to DID estimates: departments in Chad that received significant oil transfers increased their wellbeing more than those disadvantaged by the oil-revenue-redistribution policy. Furthermore, departments closest to the capital city of N'Djamena benefited from spillover effects and scored higher wellbeing. Several sensitivity and robustness checks show these results to be robust. We conclude that an inclusive governance of natural resources in Chad, especially oil, requires the government to better target oil-revenueredistribution policies according to local development needs and toward the poorest departments. More precisely, deprived departments such as Haraze Mangueigne, Lac Léré, Tibesti, and Dar Tama should benefit from oil-revenues to a larger extent in order to increase their investments in infrastructures, especially schools, hospitals, roads, and electricity. By thus increasing wellbeing in disadvantaged departments, the whole country would benefit in terms of social and political stability, which are crucial vectors of sustainable development.

Acknowledgments. This study was carried out with financial and scientific support from the Partnership for Economic Policy (PEP), with funding from the Department for International Development (DFID) of the United Kingdom (or UK Aid) and the Government of Canada through the International Development Research Center (IDRC). The authors are grateful to Luca Tiberti and an anonymous referee for enriching comments and suggestions. The usual disclaimer applies.

Conflict of interest. There is no conflict of interest.

\section{References}

Acemoglu D, Autor DH and Lyle D (2004) Women, war, and wages: the effect of female labor supply on the wage structure at midcentury. Journal of Political Economy 112, 497-551.

Akitoby B and Coorey S (2012) Oil Wealth in Central Africa: Policies for Inclusive Growth. Washington, DC: International Monetary Fund.

Alkire S and Santos ME (2010) Actual multidimensional poverty: a new index for developing countries. Background Paper for the 2010 Human Development Report, United Nations Development Programme, New York, USA.

Allcott and Keniston D (2014) Dutch disease or agglomeration? The local economic effects of natural resource booms in modern America. Working Paper 20508, National Bureau of Economic Research.

Araar A (2009) The hybrid multidimensional index of inequality. Working Paper 09-45, Centre Interuniversitaire sur le Risque, les Politiques Economique et sur L'emploi (CIRPEE).

Araar A (2016) Percentile weights regression. PEP-PMMA Technical Note Series. Available at http://dasp.ecn.ulaval.ca/temp/PEP_Notes_Araar_01_June_2016.pdf. 
Aragon FM and Rud JP (2013) Natural resources and local communities: evidence from a Peruvian gold mine. Economic Policy 5, 1-25.

Arellano-Yanguas J (2011) Aggravating the resource curse: decentralization mining and conflict in Peru. Journal of Development Studies 474, 617-638.

Arreaza A and Reuter A (2012) Can a mining windfall improve welfare? Evidence from Peru with municipal level data. CAF Working Paper 2012/04, Caracas, Venezuela.

Asselin L-M (2009) Analysis of Multidimensional Poverty: Theory and Case Studies. IDRC: Springer Editions.

Bauer A, Iwerks R, Pellegrini M and Venugopal V (2016) Subnational governance of extractives: fostering national prosperity by addressing local challenges. Policy Paper, Natural Resource Governance Institute.

Behbudi D, Mamipour S and Karami A (2010) Natural resource abundance, human capital and economic growth in the petroleum exporting countries. Journal of Economic Development 35, 81-102.

Beine M, Coulombe S and Vermeulen WN (2015) Dutch disease and the mitigation effect of migration: evidence from Canadian provinces. The Economic Journal 125, 1574-1615.

Caselli F and Michaels G (2013) Do oil windfalls improve living standards? Evidence from Brazil. Applied Economics 5, 208-238.

Cash AC (2012) Corporate social responsibility and petroleum development in Sub-Saharan Africa: the case of Chad. Resources Policy 37, 144-151.

CCMOR (2012) Rapports Annuels 2004-2012. Collège de Contrôle et de Surveillance des Revenus Pétroliers, N'djamena, Chad.

Chabé-Ferret S (2015) Analysis of the bias of matching and difference-in-difference under alternative earnings and selection processes. Journal of Econometrics 185, 110-123.

Cust J and Rusli RD (2014) The economic spillovers from resource extraction: a partial resource blessing at the subnational level? Economic Growth Centre Working Paper Series 1402, Nanyang Technological University, School of Social Sciences, Economic Growth Centre.

Cust J and Viale C (2016) Is there evidence for a subnational resource curse? Policy Paper, Natural Resource Governance Institute.

Ebeke C, Omgba LC and Laajad R (2015) Oil, governance and (mis) allocation of talents in developing countries. Journal of Development Economics 114, 126-141.

ECA AU AfDB and UNDP (2014) MDG report 2014: assessing progress in Africa toward the Millennium Development Goals. Available at http://www.uneca.org.

EITI (2014) Rapport ITIE Tchad - année 2014. Extractive Industries Transparency Initiative. Available at https://eiti.org/chad.

Fondo S, Gadom DG and Totouom FAL (2013) Soutenabilité économique d'une ressource épuisable: Cas du pétrole tchadien. African Development Review 25, 344-357.

Gadom DG and Mboutchouang KA (2016) Cross-county poverty comparisons in Chad: the impact of the oil revenues redistribution policy. Région et Développement 44, 61-78.

Gajdos T and Weymark J (2005) Multidimensional generalized Gini indices. Economic Theory 26, 471-496.

Goldin C and Olivetti C (2013) Shocking labor supply: a reassessment of the role of World War II on women's labor supply. American Economic Review 103, 257-262.

Gylfason T (2001) Natural resources, education, and economic development. European Economic Review 45, 847-859.

Hoinathy R (2013) Pétrole et Changement Social au Tchad: Rente Pétrolière et Monétisation des Relations Économiques et Sociales dans la Zone Pétrolière de Doba. Paris: Karthala Editions.

Imbens GW and Wooldridge J (2009) Recent developments in the econometrics of program evaluation. Journal of Economic Literature 47, 5-86.

IMF (2012) IMF gathers ideas on best use of natural resource. Available at https://www.imf.org/en/News/ Articles/2015/09/28/04/53/socar100312a.

INSEED (2013) Profil de pauvreté au Tchad en 2011. National Institute of Statistical Economic and Demographic Studies, Chad.

Lippert A (2014) Spill-overs of resource boom: evidence from Zambian copper mines. Technical Report, Oxford Centre for the Analysis of Resource Rich Economies, University of Oxford, UK.

Lipschutz K and Henstridge M (2013) Mapping International Efforts to Strengthen Extractive Governance. Oxford: Oxford Policy Management. 
Loayza N and Rigolini J (2016) The local impact of mining on poverty and inequality: evidence from the commodity boom in Peru. World Development 84, 219-234.

Mabali A and Mantobaye M (2017) Oil and regional development in Chad: assessment of the impact of the Doba Oil project on poverty in the host region. African Development Review 29, 42-55.

Maguire K and Winters JV (2017) Energy boom and gloom? Local effects of oil and natural gas drilling on subjective well-being. Growth and Change 48, 590-610.

Mehlum H, Moene KO and Torvik R (2006) Institutions and the resource curse. The Economic Journal 116, 1-20.

Monge C and Viale C (2011) Local level resource curse: the "Cholo Disease" in Peru. Working Paper, Natural Resource Governance Institute.

Mundlak Y (1978) On the pooling of time series and cross section data, Econometrica 46, 69-85.

Ndang TS and Nan-Guer KB (2011) Réduction de la pauvreté et croissance économique: cas du Tchad. AERC Collaborative Research Project on Understanding the Links between Growth and Poverty in Africa, Nairobi, Kenya.

Postali FAS (2009) Petroleum royalties and regional development in Brazil: the economic growth of recipient towns. Resources Policy 34, 205-213.

Postali FAS and Nishijima M (2013) Oil windfalls in Brazil and their long-run social impacts. Resources Policy 38, 94-101.

Ross M (2004) What do we know about natural resources and civil war? Journal of Peace Research 41, 337-356.

Sachs JD and Warner AM (1995) Natural resource abundance and economic growth. Working Paper 5398, National Bureau of Economic Research.

Sachs JD and Warner AM (1999) The big push, natural resource booms and growth. Journal of Development Economics 59, 43-76.

Sachs JD and Warner AM (2001) The curse of natural resources. European Economic Review 45, 827-838.

Sala-i-Martin X and Subramanian A (2003) Addressing the natural resource curse: an illustration from Nigeria. Working Paper 9804, National Bureau of Economic Research.

Sandbu ME (2006) Natural wealth accounts: a proposal for alleviating the natural resource curse. World Development 34, 1153-1170.

Segal P (2011) Resource rents, redistribution, and halving global poverty: the resource dividend. World Development 39, 475-489.

Thorbecke E (2013) The interrelationship linking growth, inequality and poverty in Sub-Saharan Africa. Journal of African Economies 22(Supplement 1), 15-48.

Ticci E and Escobal J (2015) Extractive industries and local development in the Peruvian highlands. Environment and Development Economics 20, 101-126.

UNDP (2013) Rapport sur le Développement Humain 2013. New York, USA: United Nations Development Programme.

Wooldridge JM (2010) Econometric Analysis of Cross Section and Panel Data, Cambridge, MA: MIT Press.

World Bank (2013) Dynamic of poverty and inequality since the emergence of oil production, Report, World Bank Africa Region.

Zambrano O, Robles M and Laos D (2014) Global boom, local impacts: mining revenues and subnational outcomes in Peru 2007-2011. Working Paper 509, Inter-American Development Bank.

Zhang J, Kornov L and Christensen P (2013) Critical factors for EIA implementation: literature review and research options. Journal of Environmental Management 114, 148-157.

\section{Appendices}

\section{Appendix A. Harmonization at the level of sub-regional departments}

Beginning with Decree No. 419/PR/MAT/02 of October 17, 2002, subnational administrative units in Chad are called regions, departments, districts, and sub-districts in decreasing order of size. Although a larger number of districts would enable a more refined analysis, the department is the smallest administrative unit used in our study. There would be two main difficulties to using the district as a unit of analysis. First, the primary sampling units used for the ECOSIT surveys largely vary from one cross-sectional dataset to another 
(especially ECOSITs 2 and 3, in our case). Second, data on oil-revenue redistribution from CCMOR do not go beyond the department level.

ECOSIT 3 and CCMOR do not cover the same number of geographical units. The first covers 20 regions and 73 departments, while CCMOR covers 12 regions and 62 departments. Nevertheless, each region and department of the CCMOR can be recovered from the ECOSIT 3. In fact, the higher number of geographical units in ECOSIT 3 derives from the subdivision of some ECOSIT 2 units, which can then be easily matched with CCMOR. We subsequently regrouped departments from ECOSIT 3 to locate the CCMOR departments that served as our baseline. The CCMOR, which is based on a former administrative division, provides the fewest number of geographical units. 
Appendix B. Construction of the ratio used to treat departments

Table A1. Demographic weights, oil-revenue shares, and ratio by region and department

\begin{tabular}{|c|c|c|c|c|c|c|c|}
\hline $\begin{array}{l}\text { Regions/ } \\
\text { Departments }\end{array}$ & $\begin{array}{l}\text { Demographic } \\
\text { weights }\end{array}$ & $\begin{array}{c}\text { Oil } \\
\text { shares }\end{array}$ & Ratio & $\begin{array}{l}\text { Regions/ } \\
\text { Departments }\end{array}$ & $\begin{array}{l}\text { Demographic } \\
\text { weights }\end{array}$ & $\begin{array}{c}\text { Oil } \\
\text { shares }\end{array}$ & Ratio \\
\hline Batha & 0.0442 & 0.0079 & 0.1792 & Chari Baguirmi & 0.0524 & 0.0105 & 0.2011 \\
\hline Batha-Ouest & 0.0179 & 0.0048 & 0.2655 & Baguirmi & 0.0190 & 0.0053 & 0.2772 \\
\hline Batha-Est & 0.0163 & 0.0020 & 0.1213 & Chari & 0.0166 & 0.0032 & 0.1907 \\
\hline Fitri & 0.0100 & 0.0012 & 0.1193 & Loug-Chari & 0.0168 & 0.0021 & 0.1253 \\
\hline Borkou & 0.0085 & 0.0031 & 0.3620 & Lac & 0.0393 & 0.0094 & 0.2395 \\
\hline Borkou & 0.0062 & 0.0021 & 0.3471 & Mamdi & 0.0202 & 0.0066 & 0.3252 \\
\hline Borkou Yala & 0.0023 & 0.0009 & 0.4025 & Wayi & 0.0191 & 0.0028 & 0.1489 \\
\hline Guera & 0.0488 & 0.0135 & 0.2764 & Logone Occidental & 0.0624 & 0.1312 & 2.1029 \\
\hline Guera & 0.0156 & 0.0067 & 0.4314 & Lac Wey & 0.0300 & 0.0655 & 2.1829 \\
\hline Abtouyour & 0.0152 & 0.0027 & 0.1777 & Dodjé & 0.0096 & 0.0197 & 2.0410 \\
\hline Barh Signaka & 0.0094 & 0.0013 & 0.1437 & Gueni & 0.0083 & 0.0198 & 2.3777 \\
\hline Mangalmé & 0.0086 & 0.0027 & 0.3136 & Ngourkosso & 0.0144 & 0.0262 & 1.8185 \\
\hline Hadjer Lamis & 0.0513 & 0.2150 & 4.1865 & Kanem & 0.0302 & 0.0041 & 0.1360 \\
\hline Dagana & 0.0171 & 0.1290 & 7.5599 & Kanem & 0.0139 & 0.0025 & 0.1767 \\
\hline Dababa & 0.0207 & 0.0322 & 1.5583 & Nord-Kanem & 0.0082 & 0.0008 & 0.0992 \\
\hline Haraze Al Biar & 0.0136 & 0.0537 & 3.9534 & Wadi-Bissam & 0.0081 & 0.0008 & 0.1037 \\
\hline Logone Oriental & 0.0706 & 0.1467 & 2.0787 & Mayo Kebbi Est & 0.0702 & 0.0117 & 0.1665 \\
\hline La Pendé & 0.0145 & 0.0508 & 3.4958 & Mayo-Boneye & 0.0214 & 0.0037 & 0.1744 \\
\hline Kouh Est & 0.0092 & 0.0215 & 2.3388 & Kabbia & 0.0207 & 0.0009 & 0.0448 \\
\hline Kouh Ouest & 0.0045 & 0.0084 & 1.8702 & Mayo-Lemié & 0.0074 & 0.0009 & 0.1214 \\
\hline
\end{tabular}


Table A1. Continued

\begin{tabular}{|c|c|c|c|c|c|c|c|}
\hline $\begin{array}{l}\text { Regions/ } \\
\text { Departments }\end{array}$ & $\begin{array}{c}\text { Demographic } \\
\text { weights }\end{array}$ & $\begin{array}{c}\text { Oil } \\
\text { shares }\end{array}$ & Ratio & $\begin{array}{l}\text { Regions/ } \\
\text { Departments }\end{array}$ & $\begin{array}{l}\text { Demographic } \\
\text { weights }\end{array}$ & $\begin{array}{c}\text { Oil } \\
\text { shares }\end{array}$ & Ratio \\
\hline La Nya & 0.0128 & 0.0246 & 1.9253 & Mont Illi & 0.0206 & 0.0061 & 0.2966 \\
\hline La Nya Pendé & 0.0098 & 0.0158 & 1.6178 & Moyen Chari & 0.0533 & 0.0382 & 0.7177 \\
\hline Monts de Lam & 0.0198 & 0.0257 & 1.2933 & Barh Koh & 0.0278 & 0.0239 & 0.8592 \\
\hline Mandoul & 0.0569 & 0.1406 & 2.4709 & Grande Sido & 0.0097 & 0.0090 & 0.9252 \\
\hline Mandoul Oriental & 0.0232 & 0.0833 & 3.5912 & Lac Iro & 0.0158 & 0.0054 & 0.3411 \\
\hline Barh Sara & 0.0197 & 0.0278 & 1.4107 & Salamat & 0.0274 & 0.0157 & 0.5729 \\
\hline Mandoul Occidental & 0.0140 & 0.0295 & 2.1049 & Barh Azoum & 0.0165 & 0.0077 & 0.4678 \\
\hline Ouaddaï & 0.0653 & 0.0140 & 0.2149 & Aboudéia & 0.0059 & 0.0067 & 1.1403 \\
\hline Ouara & 0.0298 & 0.0113 & 0.3808 & Haraze Mangueigne & 0.0050 & 0.0013 & 0.2563 \\
\hline Abdi & 0.0097 & 0.0012 & 0.1266 & Tandjilé & 0.0600 & 0.0527 & 0.8796 \\
\hline Assoungha & 0.0259 & 0.0015 & 0.0569 & Tandjilé Est & 0.0231 & 0.0211 & 0.9146 \\
\hline Mayo Kebbi Ouest & 0.0511 & 0.0041 & 0.0799 & Tandjilé Ouest & 0.0369 & 0.0316 & 0.8578 \\
\hline Mayo-Dallah & 0.0303 & 0.0025 & 0.0809 & Barh-El-Gazal & 0.0233 & 0.0061 & 0.2630 \\
\hline Lac Léré & 0.0208 & 0.0016 & 0.0785 & Barh-El-Gazal Sud & 0.0177 & 0.0043 & 0.2424 \\
\hline Wadi Fira & 0.0460 & 0.1029 & 2.2345 & Barh-El-Gazal Nord & 0.0056 & 0.0018 & 0.3280 \\
\hline Biltine & 0.0153 & 0.0949 & 6.1961 & Ennedi & 0.0152 & 0.0505 & 3.3213 \\
\hline Darh Tama & 0.0162 & 0.0032 & 0.1940 & Ennedi & 0.0055 & 0.0490 & 8.9214 \\
\hline Kobé & 0.0145 & 0.0049 & 0.3361 & Wadi Hawar & 0.0097 & 0.0015 & 0.1577 \\
\hline Sila & 0.0277 & 0.0020 & 0.0737 & Tibesti & 0.0023 & 0.0219 & 9.5085 \\
\hline Kimiti & 0.0277 & 0.0012 & 0.0442 & Tibesti Est & 0.0013 & 0.0213 & 16.371 \\
\hline Djourouf Al Almar & 0.0074 & 0.0008 & 0.1107 & Tibesti Ouest & 0.0010 & 0.0006 & 0.6098 \\
\hline
\end{tabular}

Note: In the absence of data on oil-revenue redistribution within the capital city N'Djamena, this region is considered as a department and its ratio greater than 1.

Source: From CCMOR (2012) and INSEED (2013). 


\section{Appendix C. Construction of the synthetic index of multidimensional wellbeing}

In a poor country like Chad, improving the distribution of basic dimensions of wellbeing should help in improving the opportunities of the deprived population and thus reduce the poverty. Based on this, assessing the improvement in the MDW becomes appropriate to evaluate the extent of the efforts to fight poverty. We apply Araar's (2009) MDW approach which is proved to be an extension of Gajdos and Weymark's (2005) MDW index. Thus, implicitly, the axioms were cross-checked. However, Araar's (2009) work enables the decomposition of the MDW index based on classical and largely accepted approaches. Asselin (2009) discusses the theoretical foundations and the techniques to estimate the MDW.

There are many dimensions of wellbeing that can be influenced by oil revenue through investments and transfers. In this study, we focused on four dimensions of wellbeing according to information available in both ECOSIT 2 and 3 databases: housing infrastructure and environmental facilities, education, health, and possession of durable goods. ${ }^{11}$ For each dimension, we used a set of primary non-monetary indicators as shown in table A2. Given the categorical structure of these indicators, the Multiple Correspondence Analysis (MCA) technique was the appropriate method to estimate MDW based on 15,954 households after appending ECOSIT 2 and 3 data:

$$
W_{i}=\frac{\sum_{k=1}^{K} \sum_{J_{k}=1}^{J_{k}} w_{j k} \cdot I_{i, J_{k}}}{K} .
$$

$K$ is the number of categorical variables, $J_{k}$ is the number of categories for indicator $k, I_{i, j_{k}}$ is the binary indicator taking 1 if the individual $i$ has the category $j_{k}$, and $w_{j_{k}}$ is the normalized first axis score of the category $j_{k}$.

The first MCA was carried out with a total of 23 variables spread over the four indicators. This step allowed the choice of the primary indicators that would be used to construct MDW scores. Two criteria served to select or eliminate variables and to conclude the MCA analysis: the first consisted of appreciating the discriminatory power of each variable over the first axis, while the second relied on the first axis ordering consistency property. The following variables were removed after the first MCA: consultation, reason of dissatisfaction, sanitary facilities, type of house, and possession of bicycle (see table A2). Therefore, three dimensions and 18 variables were retained to run the second MCA. The results showed that the explanatory power - percentage of total inertia - of the first axis increased from 68.53 per cent to 79.28 per cent for the first and second MCA, respectively. The discriminatory power of the first axis is more than 50 per cent and can be named the MDW access axis. The first axis ordinary consistency property was checked for all the remaining variables within the second MCA.

\footnotetext{
${ }^{11}$ These dimensions reflect the sectors in which most oil revenues are spent, according to the National Poverty Reduction Papers (NPRP1 from 2003 to 2006 and NPRP2 from 2008 to 2011).
} 
Table A2. Descriptive statistics and results of the multiple correspondence analysis

\begin{tabular}{|c|c|c|c|c|c|c|}
\hline \multirow{2}{*}{$\begin{array}{l}\text { Dimensions of indicators/ } \\
\text { modalities }\end{array}$} & \multicolumn{2}{|c|}{$\%$} & \multicolumn{2}{|c|}{ First MCA } & \multicolumn{2}{|c|}{ Second MCA } \\
\hline & 2003 & 2011 & Coord. & Contrib. & Coord. & Contrib. \\
\hline
\end{tabular}

Dimension 1: Housing infrastructure and environmental facilities

\begin{tabular}{|c|c|c|c|c|c|c|}
\hline \multicolumn{7}{|l|}{ Occupational status } \\
\hline 1. Owner in urban area & 11.80 & 38.09 & 4467 & 73 & 4073 & 77 \\
\hline 2. Owner in rural area & 61.76 & 30.07 & -766 & 20 & -697 & 21 \\
\hline 3. Not owner in urban area & 16.28 & 29.27 & 3915 & 44 & 3547 & 47 \\
\hline 4. Not owner in rural area & 10.17 & 2.57 & -551 & 1 & -500 & 1 \\
\hline \multicolumn{7}{|l|}{ Residence area } \\
\hline 1. Urban & 28.07 & 67.36 & 4,222 & 116 & 3,840 & 123 \\
\hline 2. Rural & 71.93 & 32.64 & -746 & 21 & -679 & 22 \\
\hline \multicolumn{7}{|l|}{ Type of house } \\
\hline 1. Single-family dwelling & 46.93 & 53.14 & -730 & 14 & & \\
\hline 2. Communal-type dwelling & 23.17 & 10.69 & 1,664 & 14 & & \\
\hline 3. Private house & 27.80 & 35.90 & 1,033 & 12 & & \\
\hline 4. Other & 2.09 & 0.27 & -937 & 0 & & \\
\hline \multicolumn{7}{|l|}{ Number of bedrooms } \\
\hline 1. One bedroom & 36.42 & 42.38 & -483 & 3 & -335 & 2 \\
\hline 2. Two to three bedrooms & 40.75 & 40.05 & -185 & 1 & -187 & 1 \\
\hline 3. Four to five bedrooms & 13.29 & 11.55 & 495 & 2 & 376 & 1 \\
\hline 4. More than five bedrooms & 9.54 & 6.03 & 1,266 & 7 & 1,069 & 7 \\
\hline \multicolumn{7}{|l|}{ Source of cooking fuel } \\
\hline 1. Electricity & 0.52 & 0.13 & 3,074 & 1 & 2,922 & 1 \\
\hline 2. Gas & 2.27 & 3.86 & 4,629 & 16 & 4,335 & 18 \\
\hline 3. Charcoal & 24.06 & 19.63 & 1,635 & 16 & 1,469 & 17 \\
\hline 4. Wood & 64.30 & 74.90 & -385 & 5 & -348 & 5 \\
\hline 5. Other & 8.85 & 1.48 & -54 & 0 & -87 & 0 \\
\hline \multicolumn{7}{|l|}{ Nature of roof } \\
\hline 1. Solid & 0.31 & 40.51 & 4,193 & 81 & 3,801 & 85 \\
\hline 2. Thatched & 99.54 & 58.55 & -494 & 9 & -450 & 10 \\
\hline 3. Other & 0.15 & 0.94 & -963 & 0 & -697 & 0 \\
\hline \multicolumn{7}{|l|}{ Nature of ground } \\
\hline 1. Cement & 4.60 & 15.35 & 5,442 & 71 & 4,990 & 76 \\
\hline 2. Clay & 89.10 & 83.16 & -294 & 3 & -275 & 4 \\
\hline
\end{tabular}


Table A2. Continued

\begin{tabular}{|c|c|c|c|c|c|c|}
\hline \multirow{2}{*}{$\begin{array}{l}\text { Dimensions of indicators/ } \\
\text { modalities }\end{array}$} & \multicolumn{2}{|c|}{$\%$} & \multicolumn{2}{|c|}{ First MCA } & \multicolumn{2}{|c|}{ Second MCA } \\
\hline & 2003 & 2011 & Coord. & Contrib. & Coord. & Contrib. \\
\hline 3. Other & 6.30 & 1.49 & -921 & 1 & -698 & 1 \\
\hline \multicolumn{7}{|l|}{ Nature of walls } \\
\hline 1. Cement & 11.57 & 25.24 & 3,484 & 64 & 3,134 & 66 \\
\hline 2. Straw/banco & 87.10 & 71.11 & -471 & 8 & -425 & 8 \\
\hline 3. Other & 1.33 & 3.65 & -638 & 1 & -538 & 1 \\
\hline \multicolumn{7}{|l|}{ Lighting type } \\
\hline 1. Modern & 9.44 & 9.32 & 4,442 & 45 & 4,117 & 50 \\
\hline 2. Not modern & 71.29 & 87.71 & -122 & 1 & -123 & 1 \\
\hline 3. Other & 19.28 & 2.97 & $-1,188$ & 7 & $-1,031$ & 7 \\
\hline \multicolumn{7}{|l|}{ Garbage vacation } \\
\hline 1. Hygienic & 31.81 & 18.46 & 1,939 & 26 & 1,752 & 27 \\
\hline 2. Non-hygienic & 68.19 & 81.54 & -393 & 5 & -336 & 5 \\
\hline \multicolumn{7}{|l|}{ Sanitary facility } \\
\hline 1. Hygienic bathroom & 36.11 & 46.41 & 602 & 6 & & \\
\hline 2. Non-hygienic bathroom & 63.89 & 53.59 & -418 & 4 & & \\
\hline \multicolumn{7}{|l|}{ Nature of toilet } \\
\hline 1. Hygienic & 16.53 & 16.64 & 3,249 & 44 & 2,931 & 46 \\
\hline 2. Non-hygienic & 83.47 & 83.36 & -343 & 5 & -309 & 5 \\
\hline \multicolumn{7}{|l|}{ Dimension 2: Education } \\
\hline \multicolumn{7}{|l|}{ Writing knowledge } \\
\hline 1. Yes & 44.11 & 36.06 & 1,318 & 17 & 1,172 & 17 \\
\hline 2. No & 55.89 & 63.94 & -382 & 5 & -340 & 5 \\
\hline \multicolumn{7}{|l|}{ Problems at school } \\
\hline 1. Yes & 81.38 & 76.37 & -292 & 3 & -263 & 3 \\
\hline 2. No & 18.62 & 23.63 & 1,264 & 13 & 1,137 & 13 \\
\hline \multicolumn{7}{|l|}{ Dimension 3: Health } \\
\hline \multicolumn{7}{|l|}{ Consultation } \\
\hline 1. Authorized person & 12.68 & 19.56 & 189 & 0 & & \\
\hline 2. Non authorized person & 1.31 & 2.46 & -643 & 0 & & \\
\hline 3. Missing & 86.01 & 77.98 & -13 & 0 & & \\
\hline \multicolumn{7}{|c|}{ Dissatisfaction at the nearest hospital } \\
\hline 1. No & 7.45 & 12.88 & 206 & 0 & & \\
\hline 2. Yes & 6.48 & 9.14 & -108 & 0 & & \\
\hline
\end{tabular}


Table A2. Continued

\begin{tabular}{|c|c|c|c|c|c|c|}
\hline \multirow{2}{*}{$\begin{array}{l}\text { Dimensions of indicators/ } \\
\text { modalities }\end{array}$} & \multicolumn{2}{|c|}{$\%$} & \multicolumn{2}{|c|}{ First MCA } & \multicolumn{2}{|c|}{ Second MCA } \\
\hline & 2003 & 2011 & Coord. & Contrib. & Coord. & Contrib \\
\hline 3. Missing & 86.07 & 77.98 & -13 & 0 & & \\
\hline \multicolumn{7}{|l|}{ Dimension 4: Durable goods } \\
\hline \multicolumn{7}{|l|}{ Own a phone } \\
\hline 1. Yes & 8.12 & 3.03 & 2,575 & 11 & 2,324 & 11 \\
\hline 2. No & 91.88 & 96.97 & -98 & 0 & -88 & 0 \\
\hline \multicolumn{7}{|l|}{ Own radio } \\
\hline 1. Yes & 27.50 & 52.04 & 1,093 & 18 & 948 & 17 \\
\hline 2. No & 72.50 & 47.96 & -580 & 10 & -503 & 9 \\
\hline \multicolumn{7}{|l|}{ Own a refrigerator } \\
\hline 1. Yes & 1.08 & 2.19 & 10,881 & 42 & 10,180 & 47 \\
\hline 2. No & 98.92 & 97.81 & -90 & 0 & -84 & 0 \\
\hline \multicolumn{7}{|l|}{ Own a fan } \\
\hline 1. Yes & 1.05 & 6.87 & 9,280 & 72 & 8,667 & 80 \\
\hline 2. No & 98.95 & 93.13 & -18 & 1 & -169 & 2 \\
\hline \multicolumn{7}{|l|}{ Own an air conditioner } \\
\hline 1. Yes & 0.22 & 1.13 & 11,841 & 22 & 11,151 & 25 \\
\hline 2. No & 99.78 & 98.87 & -44 & 0 & -41 & 0 \\
\hline \multicolumn{7}{|l|}{ Own a car } \\
\hline 1. Yes & 1.05 & 2.30 & 8,433 & 32 & 7,922 & 36 \\
\hline 2. No & 98.95 & 97.70 & -87 & 0 & -82 & 0 \\
\hline \multicolumn{7}{|l|}{ Own a bicycle } \\
\hline 1. Yes & 10.32 & 17.97 & 602 & 3 & & \\
\hline 2. No & 89.68 & 82.03 & -159 & 1 & & \\
\hline
\end{tabular}

Note: For the occupational status of housing, the milieu should be considered (urban/rural factor). In urban areas, owning a house is an indicator of wealth, but the reverse is true in rural areas. For this purpose, we crossed this categorical variable with the variable of residence area to generate a new categorical variable with four modalities. Source: ECOSIT 2 and 3.

Cite this article: Gadom GD, Mboutchouang KA, Araar A (2018). The impact of oil revenues on wellbeing in Chad. Environment and Development Economics 23, 591-613. https://doi.org/10.1017/ S1355770X18000281 